DOI 10.37882/2223-2982.2020.11-2.04

\title{
НЕКОТОРЫЕ ПОДХОДЫ К ФОРМИРОВАНИЮ КОММУНИКАТИВНЫХ КОМПЕТЕНЦИЙ У МЛАДШИХ ШКОЛЬНИКОВ НА УРОКАХ РОДНОГО ЯЗЫКА
}

\section{SOME APPROACHES TO THE FORMATION OF COMMUNICATIVE COMPETENCIES OF PRIMARY SCHOOL CHILDREN AT THEIR NATIVE LANGUAGE LESSONS}

\section{N. Vasileva}

E. Nikiforova

Summary: The article is devoted to the problem of the formation of communicative competence at the syntactic level among students of primary school age. The importance of polypredicative sentences is considered as a means of developing the communicative and cognitive potential of students in their native language. The inclusion of polypredicative sentences in the curriculum of the 4th grade syntax course will help maintain the current level of knowledge of the native language.

Keywords: Sakha language, native language, communicative competence, language education, syntax, polypredicative sentence.

\author{
Васильева Надежда Николаевна \\ Соискатель, Северо-Восточный федеральный \\ университет имени М.К. Аммосова \\ vasna73@mail.ru \\ Никифорова Евдокия Павловна \\ Д.п.н., профессор, Северо-Восточный федеральный \\ университет имени М.К. Аммосова
}

Аннотация: Статья посвящена проблеме формирования коммуникативной компетенции на синтаксическом уровне у обучающихся младшего школьного возраста. Значимость полипредикативных предложений рассматривается как средство развития коммуникативного и когнитивного потенциала обучающихся на родном языке. Включение в программу курса синтаксиса в 4 классе полипредикативных предложений будут способствовать поддержке актуального уровня владения родным языком.

Ключевые слова: язык саха, родной язык, коммуникативная компетенция, языковое образование, синтаксис, полипредикативное предложение.

матизирующие знания о родном языке, умения формировать и формулировать мысли, создавать собственные тексты различных типов. Другими словами, коммуникативная компетенция обеспечивает единство языка как средства и речи как способа реализации в деятельности.

Как правило, в дошкольном возрасте дети овладевают родным языком на бессознательном уровне на основе естественной речевой среды. Они ещё не знают о существовании норм языка, но без каких-либо проблем осваивают его систему и правильно употребляют в устной речи. Ребёнок, который освоил систему родного языка, то есть накопил свой индивидуальный речевой опыт, интуитивно способен формулировать мысль в различные предложения, следовательно, и в тексты. Модели предложений обозначают связи, свойственные действительности и преломленные в языковом сознании людей - носителей определённого языка, таким образом создавая картину мира на синтаксическом уровне, в них отражаются отношения, выражающие конкретные мысли, подталкивающие к определённому видению картины мира [4]. В зависимости от того, какие синтаксические модели обучающийся использует в своей речи, можно определить уровни его когнитивного и коммуникативного развития, а также потенциал овладения родным языком. Действительно, коммуникативная функция языка реали- 
зуется через синтаксис, без синтаксиса нет связной речи и без него не предоставляется возможным развитие речи в принципе. Как отмечает Б.Ю. Норман, «синтаксические модели закономерно отражают объективную действительность» [3, с. 38], «именно возможности синтаксиса диктуют, или подсказывают нам, как «увидеть» ситуацию, помогают понять, что она, собственно, собой представляет» [3, с. 40], «синтаксис, образно говоря, - это рельсы, по которым движется поезд познания» [3, с. 57]. В связи с этим формирование коммуникативной компетенции на синтаксическом уровне занимает особое место в системе обучения родному языку и должно стать одной из главных задач развития речи обучающихся.

Между тем, синтаксис является одним из сложных уровней речи. Если способность определять фонемные звуки и слова на слуху ребёнок обнаруживает ещё в дошкольном возрасте, то синтаксическая структура собственной речи для него может оставаться «неуловимой» и в годы обучения в школе. Данный факт подчёркивает важность обучения синтаксису в начальных классах. Как справедливо отмечает Е.А. Хамраева, «особенность современного детства такова, что сегодня требуется специальное развитие видов речевой деятельности и у детей - носителей языка» [5, с. 61]. Во-первых, современные дети саха являются билингвами, с раннего детства овладевают двумя языками. Как показывает практика, у детей начальных классов разный уровень билингвизма, в основном у них преобладает стихийный билингвизм и очень редко сбалансированное двуязычие. Во-вторых, интеграционные тенденции информационно-коммуникационных технологий постиндустриального общества влияют и на общее развитие современных детей. Их сейчас называют представителями диджитал-поколения, детьми, которые родились «с гаджетами в руках», они интегрированы в цифровую среду, их повседневная жизнь не представляется без смартфонов, планшетов, которые являются необходимыми инструментами их жизнедеятельности и интерактивной коммуникации, вместе с тем они открыты миру, им нравится искать и создавать новое и т.д. Несомненно, ранний билингвизм и отличное владение современными информационными технологиями влияют на качество владения родным языком.

Наши наблюдения свидетельствуют о том, что практика обучения родному (якутскому) языку в начальных классах не обеспечивает в должной мере формирование коммуникативной компетенции на синтаксическом уровне. За весь период начального обучения курс раздела ограничивается изучением только простых предложений, что не даёт в полной мере использовать дидактический потенциал синтаксиса для коммуникативного и когнитивного развития обучающихся. Кроме того, это показатель того, что не совсем достаточно оценивается когнитивный и коммуникативный потенциал обучающихся как носителей родного языка.
В настоящее время в изучении синтаксиса преобладает структурный подход, а семантический аспект, направленный на формирование умений формулировать мысли в форме простых предложений, в основном, происходит на спонтанном уровне. Обучающиеся являются носителями родного языка, поэтому смысл каждого предложения понимают на ментальном уровне, в контексте, но в процессе сознательного изучения синтаксиса родного языка закономерно обнаруживают трудности в соотношении структуры и семантики предложения. В связи с этим на уроках родного языка в большей степени данная проблема не акцентируется, а создается лингвистическое поле, где структурно-семантический подход реализуются в достаточно упрощённом понимании - от освоения грамматических правил к употреблению в речи.

Между тем, результаты наших исследований показывают, что в 3 классе у большинства обучающихся наступает промежуточный этап к переходу на новый уровень коммуникативного развития на синтаксическом уровне. В это время в их письменной речи начинают появляться сложные синтаксические конструкции. С одной стороны, данному процессу способствует установление скорости письма, а с другой стороны, в соответствии с возрастом продолжается формирование коммуникативных умений, развивается мышление, а познавательная деятельность способствует обогащению не только словарного запаса, но и синтаксического строя речи. В 4 классе обучающиеся демонстрируют способность стихийно употреблять в письменной речи различные модели полипредикативных предложений, но продолжают осваивать синтаксис родного языка на материале простого предложения, выполнять одни и те же типовые задания. В связи с этим очевидным является тот факт, что на данном этапе необходим новый синтаксический уровень в содержании обучения родному языку. Об этом свидетельствуют и базовые синтаксические умения, сформированные у обучающихся на основе простых предложений и показывающие об их готовности к сознательному освоению полипредикативных предложений. Обучающиеся умеют распознавать и создавать простые предложения, и на их основе производить различные синтаксические действия, включающие анализ, синтез, классификацию базовых синтаксических единиц.

Полипредикативные предложения как средства формирования коммуникативных компетенций на синтаксическом уровне: 1) предоставляют возможность научить обучающихся элементарным способам семантического анализа синтаксических конструкций, что активизирует речемыслительную деятельность на родном языке; 2) выступают для обучающихся инструментом при обобщении ими ситуаций, событий и действий, а также в определении их временных, противительных, причинных и других отношений непосредственно в дискурсе. 
Горелов И.Н., Седов К.Ф. отмечают, что после периода «самоучения» языка, в школьные годы овладение родным языком проходит под знаком дискурса. «Структура дискурса является отражением (и выражением) особенностей языковой личности, а совершенствование речевой деятельности по производству текстов будет отражать эволюцию его коммуникативной компетенции» [2, с.235]. Текст как продукт дискурсивного мышления создаёт ситуацию действительности, где представляется фреймовое моделирование окружающего мира на основе знаний и личного опыта человека. В этом плане, по мнению С.Г. Виноградовой, сложное предложение выступает не только в качестве языкового выражения, но и форматом знания, который является частью язы- кового сознания. Она отмечает, что «формат сложного предложения как форма представления знаний содержит сведения о событиях, на тех или иных основаниях, связываемых индивидом в ходе познания окружающего мира и его интерпретации с помощью языка» [1], то есть употребление полипредикативных предложений в тексте показывает уровень коммуникативного и когнитивного развития человека.

Таким образом, включение в программу курса синтаксиса в 4 классе полипредикативных предложений будут способствовать поддержке актуального уровня владения родным языком и системному формированию коммуникативной компетенции на синтаксическом уровне.

\section{ЛИТЕРАТУРА}

1. Виноградова С.Г. Когнитивные доминанты реализации сложного предложения в речи // IV Международная научно-практическая конференция. РАУ, 2019. - C.240-245.

2. Горелов И.Н., Седов К.Ф. Основы психолингвистики. - М.: Лабиринт, 2004. - 320 с.

3. Норман Б.Ю. Когнитивный синтаксис русского языка. - М.: Флинта, Наука, 2018. - 252 с.

4. Одинцова И.В. Когнитивная лексикология и когнитивный синтаксис в лингводидактике // Мир русского слова. - № 2, 2018. - С. 75-80

5. Хамраева Е.А. Теория и методика обучения детей-билингвов русскому языку. - СПб., 2017. - 155 с.



